\title{
Alexander Wilson, the Scot who founded American Ornithology
}

By Edward H. Burtt, Jr. and William E. Davis, Jr. 2013. The Belknap Press of Harvard University Press, Cambridge, MA, USA, 02138. 464 pages, 35.00 USD, Cloth.

Alexander Wilson is considered the Father of American Ornithology but he is little known outside the bird world. The year 2013 marks the $200^{\text {th }}$ anniversary of Wilson's death and 2014 marks the $200^{\text {th }}$ anniversary of the completion of American Ornithology. The timing is perfect!

When an infant, Alexander Wilson was christened by Dr John Witherspoon, who later became president of the College of New Jersey, the forerunner of Princeton University. Nicknamed "Sandy," he attended LatinGrammar School in Paisley, Scotland. He was apprenticed as a weaver, but established a reputation as a poet (one anonymous poem sold 100,000 copies) and a labour activist.

In 1794, at age 28, Wilson sailed for Philadelphia, never to return. In 1801, as a teacher in Milestown, Pennsylvania, he wrote a widely published poem, "Oration," to celebrate the inauguration of President Thomas Jefferson. The "watershed event" of his life was his move in 1802 to Kingsessing at Gray's Ferry, close to the home and garden of naturalist John Bartram, who became his constant source of encouragement. In 1804 Wilson was appointed assistant editor at the Bradford and Inskeep publishing house in Philadelphia. By 1808 Wilson was able to publish volume 1 of his own American Ornithology, followed by volumes 2 in 1810, and volumes 3 through 7 before he died suddenly of dysentery at age 47 on 23 August 1813 . After his death, Volume 8 was seen through the press and Volume 9 put together by George Ord in 1814.

Within their longest chapter (three, pages 63 through 279), Burtt and Davis provide a detailed explanation of Wilson's artistic progress from a novice illustrator into an accomplished artist: from previously unavailable pencil sketches through pen and ink drawings, and then from draft paintings to the final product, each plate individually coloured by hand. Wilson broke with the $18^{\text {th }}$-century tradition of portraying single birds sitting on miniaturized trees and began painting multiple species with naturalistic backgrounds, in poses that facilitated identification. This chapter should be of great interest to artists as well as ornithologists. Wilson laid the groundwork for future artist-naturalists, especially
John James Audubon, whom Wilson first met in 1810 in Louisville, Kentucky, where they hunted birds together and parted amicably.

Wilson's friendship with George Ord began with their joint trips to Cape Cod in 1811. Although Ord, unlike Wilson, despised Audubon, I especially enjoyed reading two anecdotes about Ord : 1) "Örd cannot resist attacking Audubon. Beginning with a rude reception on an April evening in the Philadelphia Academy of Natural Sciences, Ord's intransigence and Audubon's ego led to increasingly bitter accusations of plagiarism on both sides until, tragically, Wilson's accomplishment was lost in the haze of charge and counterchange..." 2) The account of George Ord's surprise to learn, when Wilson died, that he was not wealthy but lived in one upstairs room, died owing money, and had a library consisting of only two books. Although Wilson wrote long and detailed travel letters and kept meticulous records of the birds he shot, Wilsons`s accurate accounts of bird behaviour were largely written from memory."

Burtt and Davis explain that Alexander Wilson was the first to have five species named for him (page ix); spend all his time studying birds (page 285); produce a formal classification of American birds within the Linnaean system (page 333); document seasonal change in avian testis size (page 316); provide anatomical detail of feathers and foot scale patterns (page 351); recognize citizen science (page 320); introduce quantification of the economic effects of birds (page 330); explore dietary and morphological detail by dissection (page 333); use behavioural, ecological and quantitative observations (page 333); and successfully underwrite a large publishing project based on subscriptions from largely middle-class individuals (page 333). American Ornithology was the first major scientific work published in the United States. Wilson's nine volumes established American scientific ornithology, set a new standard for scientific description, and elevated nature writing to a distinctly American tradition (page 333).

On occasion, I would have welcomed a little more detail, perhaps in end notes if not in the text, explaining to today's readers that the Black-bellied and Semi- 
palmated Plover bred in Wilson's time in not-yet-discovered Arctic regions, making clear that Wilson had observed the injury-feigning of the Piping, not the Semipalmated, Plover.

I would also mention that "many," not "most," of the new bird names originated from Linnaeus (page 83); that Steller's 'Kampsehatlea' refers to present-day 'Kamchatka' (page 128); that the Willet nests on dry ground (page 280); and that Philosophic Transactions was one of the first two scientific journals in the world (page 381).
Wilsons's skills as a writer, a taxonomist and especially as an observer of bird behaviour. Readers will accept this book's evidence that Wilson's nine volumes were of even greater importance than those of Audubon. The cost is below that of similar books and should result in the first printing of five thousand copies requiring a reprint within a year. It deserves to sell steadily for twenty more years.

C. Stuart Houston

863 University Drive, Saskatoon, SK, Canada, S7N 0J8 